\title{
LETTERS
}

\section{What matters most}

In what can certainly be considered another beat of a well-worn drum, Dr. Tanuseputro makes the case that "what matters most" with regard to end-of-life care is "increasing the reach of palliative care to prevent undue suffering and the excessive use of medical aid in dying [MAiD]." ${ }^{1}$ We have heard this argument time and again in the period leading up to and after the formal legalization of MAiD in Canada last year, and this latest salvo continues to perpetuate an unnecessary and potentially harmful dichotomy: that MAiD is a choice of last resort and an alternative to palliative care, rather than an integral part of what we can provide patients at the end of life.

Those in the MAiD-provider community in Canada would not hesitate to say that we have the deepest respect and admiration for the work done by family physicians, palliative care specialists, nurses and other health care staff who look after patients as death draws near, and we emphasize that their hard work and commitment does not simply vanish when a patient chooses to seek MAiD. Many patients who seek MAiD do not wish to hasten their death immediately; but wish to be comforted and reassured that should they reach a certain threshold of suffering, there will be an option that can bring them a peaceful and painless end to their distress. There are some aspects of suffering that no degree of counselling, therapy or symptom management can ameliorate, and it is both inhumane and paternalistic to force patients to try to find meaning and dig- nity where they feel there is none. It is past the time for all of us involved in endof-life care to work together to best serve our patients, rather than to silo ourselves into opposing camps in which each believes that we have the monopoly on doing the right thing.

\section{Keddy Adams MD}

Family physician, Chilliwack, BC

\section{Gerald P. Ashe MD}

Family physician, Brockville, Ont. Janice Chisholm MD

Associate professor, Departments of

Critical Care, Anesthesia, Pain

Management \& Perioperative Medicine, Dalhousie University, Halifax, NS

\section{Tanja Daws MBChB}

General practitioner, Courtenay, BC

Stefanie Green MD

President CAMAP (Canadian Association of MAID Assessors and Providers), Physician, Victoria, BC

\section{Tim Holland MD}

Family physician, Colchester East Hants

Health Centre, Truro, NS

\section{Marie-Clare Hopwood MD}

General practitioner-palliative care physician, Oceanside Community,

Parksville, BC

\section{Jean Marmoreo MD}

Family physician, Wellpoint Family

Practice, Toronto, Ont.

\section{Adam McDiarmid MD}

Anesthesiologist, Department of Anesthesia Lions Gate Hospital; Clinical Assistant Professor, UBC Department of Anesthesia, Pharmacology, and Therapuetics, Vancouver, BC

\section{Rick Morcom MD}

General practitioner, Riverside-Albert, NB

\section{Jesse A. Pewarchuk MD}

General internal medicine specialist,

Victoria, BC

\section{Jonathan Reggler MB BChir}

Family physician, Courtenay, BC

\section{Chantal Perrot MD}

Family physician, Toronto, Ont.

\section{James Rudnik MD}

White Rock Internal Medicine, White Rock, BC

\section{Pat Smith MD}

Hamilton Health Sciences, Hamilton, Ont.

\section{Christopher Sun MD}

Family physician, Toronto, Ont.

\section{Konia Trouton MD}

General practitioner, Victoria, BC

\section{Edward S. Weiss MD}

Family physician, Toronto, Ont.

\section{Francois de Wet MBChB}

Chief of Staff, Rural Health, Baie Verte

Peninsula Health Centre - Central Health, Baie Verte, NL

\section{Ellen Wiebe MD}

Family physician, Vancouver, BC

Lianne Yoshida MD

General practitioner, Halifax, NS

Cite as: CMAJ 2017 May 1;189:E642. doi: $10.1503 / \mathrm{cmaj} .732941$

\section{Reference}

1. Tanuseputro P. Medical aid in dying: What matters most? CMAJ 2017;189:E99-100.

Competing interests: Gerald Ashe, Tanja Daws, Jean Marmoreo, Chantal Perrot, James Rudnik, Marie-Clare Hopwood, Konia Trouton, and Edward Weiss are members of the Physicians' Advisory Council of Dying with Dignity Canada. Tanja Daws, Stefanie Green, and Jesse Pewarchuk are directors of the Canadian Association of MAiD Assessors and Providers (CAMAP). 